\title{
CAE Regimen
}

National Cancer Institute

\section{Source}

National Cancer Institute. CAE Regimen. NCI Thesaurus. Code C63379.

A regimen consisting of cyclophosphamide, doxorubicin and etoposide used for the treatment of extensive-stage small cell lung cancer. 